\author{
УДК 351.79 \\ DOI: https://doi.org/10.36910/6775-2313-5352-2019-15-2 \\ Вісин О.О., к.і.н., доцент кафедри цивільної безпеки \\ Федорчук-Мороз В.I. , к.т.н., доцент кафедри цивільної безпеки \\ Луцький НТУ
}

\title{
ОСНОВНІ АСПЕКТИ ДОМЕДИЧНОЇ ДОПОМОГИ
}

У статті висвітлено основні аспекти домедичної допомоги. Наведена нормативно правова база підгрунтя проведення навчання з домедичної допомоги. Висвітлено програми за якими проводиться навчання з домедичної допомоги постраждалому та наведено перелік навичок, якими повинні оволодіти слухачі після закінчення навчання.

В Україні середній показник смертності внаслідок надзвичайних ситуачій - 130-135 осіб на 100 тис. населення (за даними ДСНС), що в 3-5 разів перевищує показники країн Свропи.

На догоспітальному етапі помирає $76 \%$ потерпілих, у лікарнях - 24\%. У розвинених країнах світу на догоспітальному етапі помирає 28\%, у лікарнях - 72\%.

Так відбувається тому, щзо, зі 100 осіб, які померли на догоспітальному етапі, приблизно 20\% отримали несумісні з життям травми, а смерть 80\% потерпілих настала внаслідок неефективної евакуаиії до лікувальних закладів $і$ неправильно організованої домедичної допомоги безпосередньо в зоні надзвичайної ситуачії.

Якщо поруч із травмованим немає людини, яка за своїми службовими обов'язками повинна володіти основними практичними навичками з рятування та збереження життя, надавати допомогу мусить той, хто поблизу. Дї рятівника мають бути швидкими, продуманими, рімучими й доиільними. Потрібно вміти робити ие правильно, адже головний принщип під час надання домедичної допомоги - не нашкодити. Хоча в надзвичайній ситуачіі зберігати спокій досить складно, допоможе в цьому чітке усвідомлення того, щяо робиш $i$ з якою метою.

Ключові слова: домедична допомога, навчання, уміння, нормативно-правова база, аптечка.

Проблема. Сучасне виробництво пов'язане перш за все 3 високотехнологічним обладнанням, автоматизованими лініями та складним електронно-механічним начинням приладів. Але водночас це динамічна, рухома та сконцентрована робота багатьох людей, які керують, слідкують за роботою та ремонтують промислове обладнання. Цим людям потрібні безпечні умови праці та своєчасна домедична допомога у разі надзвичайної ситуації чи загострення хвороби.

За статистикою Всесвітньої організації охорони здоров'я, серцево-судинні захворювання $\epsilon$ лідерами в рейтингу смертності населення в Україні та країнах Європи. Нерідко хвороби серця чи інсульт можуть викликати раптове погіршення стану людини та зупинку серця на очах у працівників підприємства. У цих випадках навички надання домедичної допомоги стають надважливими [1].

Першочерговим завданням для вирішення зазначеної проблеми є забезпечення якомога раннього початку надання домедичної допомоги постраждалим. Сучасною медичною наукою визначено концепцію так званої «золотої години», астрономічна година (60 хв.) з моменту отримання травми або ушкодження, протягом якого має бути надано максимальний обсяг медичної допомоги постраждалому з метою порятунку його життя та здоров’я [2].

Найголовніше, це необхідність забезпечення якнайшвидшого початку надання домедичної допомоги безпосередньо на місці аварії, нещасного випадку але дотримуючись всіх протоколів $з$ надання домедичної допомоги потерпілому. Досвід найбільш розвинених країн світу свідчить про те, що для досягнення цього недостатньо сил і засобів державної системи охорони здоров'я. Для забезпечення своєчасності невідкладної домедичної допомоги в усіх цивілізованих країнах світу широкого застосування набула практика залучення до вирішення зазначеної проблеми окремих категорій немедичних працівників шляхом запровадження навчання навичкам надання домедичної допомоги [2].

Відповідно до ст. 18 Закону України «Про охорону праці» від 14 жовтня 1992 р. № 2694XII, працівники під час прийняття на роботу і в процесі роботи повинні проходити за рахунок роботодавця інструктаж, навчання 3 питань охорони праці, надання першої медичної допомоги 
потерпілим від нещасних випадків і правил поведінки у разі виникнення аварії. Найчастіше ці інструктажі проводять самі фахівці з охорони праці.

Отже, до прибуття медичних працівників підприємства або фахівців екстреної медичної допомоги працівники мають надати постраждалому необхідну допомогу відповідно до 29 Порядків надання домедичної допомоги особам при невідкладних станах, затверджених наказом Міністерства охорони здоров’я України від 16 червня 2014 р. № 398.

Щодо формулювання термінів:

- домедична допомога - це невідкладні дії та організаційні заходи, спрямовані на врятування та збереження життя людини у невідкладному стані та мінімізацію наслідків впливу такого стану на іiї здоров’я, що здійснюються на місці події особами, які не мають медичної освіти, але за своїми службовими обов'язками повинні володіти основними практичними навичками 3 рятування та збереження життя людини, яка перебуває у невідкладному стані, та відповідно до закону зобов'язані здійснювати такі дії та заходи;

- екстрена медична допомога - це медична допомога, яка полягає у здійсненні працівниками системи екстреної медичної допомоги відповідно до Закону невідкладних організаційних, діагностичних та лікувальних заходів, спрямованих на врятування і збереження життя людини у невідкладному стані та мінімізацію наслідків впливу такого стану на іiї здоров'я;

- парамедик - немедичний працівник, який пройшов спеціальну підготовку з питань надання невідкладної допомоги за 120-годинною навчально-тренувальною програмою при спеціальному учбово-тренувальному центрі i раз на три роки проходить відповідну перепідготовку за 30-годинною програмою;

- рятувальник - немедичний працівник, який пройшов спеціальну підготовку 3 питань надання невідкладної допомоги за 48-годинною навчально-тренувальною програмою при спеціальному учбово-тренувальному центрі i раз на три роки проходить відповідну перепідготовку за 18-годинною програмою;

- санітарний інструктор - немедичний працівник, який пройшов спеціальну підготовку 3 питань надання невідкладної допомоги за 12-годинною навчально-тренувальною програмою при спеціальному учбово-тренувальному центрі і раз на три роки проходить відповідну перепідготовку за 6-годинною програмою.

Основна мета домедичної допомоги - усунення причин, що загрожують життю постраждалого на момент травмування, та попередження розвитку важких ускладнень. Оптимальний термін надання першої медичної допомоги - до 30 хв. після отримання травми. При зупинці дихання цей термін скорочується до 5-10 хв.

Обсяг домедичної допомоги включає:

- діставання постраждалих із-під завалів, винос (вивіз) з осередку ураження;

- тимчасова зупинка зовнішньої кровотечі шляхом: накладання джгута для зупинки крові (стандартного або імпровізованого), пов'язки, та пальцьове стиснення магістральних судин;

- усунення асфіксії шляхом вивільнення верхніх дихальних шляхів від слизу, крові, грунту i можливих сторонніх тіл, надання визначеного положення тілу (при западанні язика, блювоті, сильній носовій кровотечі) і проведення штучної вентиляції легень (рот у рот, рот у ніс, S-подібна трубка тощо);

- закритий масаж серця;

- введення знеболюючих засобів за допомогою шприц-тюбику;

- накладання асептичної пов'язки на рану і опікову поверхню, накладання окклюзійної пов'язки при проникаючих пораненнях грудної клітини 3 використанням прогумованої оболонки індивідуального перев'язувального пакета;

- іммобілізацію ушкодженої ділянки тіла найпростішими засобами з використанням табельних і підручних засобів;

- надівання протигазу при перебуванні на зараженій місцевості;

- введення враженим отруйними речовинами антидотів;

- часткова санітарна обробка; введення антибіотиків, сульфаніламідних препаратів, протиблювотних засобів з АI-2;

- дегазація заражених ділянок шкіри та одягу, що до неї прилягає, за допомогою індивідуального протихімічного пакету. [2].

Для успішного результату замало лише бажання надати допомогу, - потрібно мати практичні навички та знати чіткий алгоритм дій. 
Дедалі більше підприємств організовують навчання своїх працівників, залучаючи до цього інструкторів 3 домедичної допомоги. Нажаль не всі інструктори, які прибувають на підприємство, мають практичний досвід надання першої допомоги та вміють якісно й доступно подати інформацію та практичні навики слухачам [1].

Над проблемою домедичної допомоги потерпілим працювали такі зарубіжні та вітчизняні вчені: Акулова О.М., Безпалий В.В., Василенко В.М., Волянський П.Б., Гур'єв С.І., Гулай А.М., Кочин І.В., Литвин Ю.П., Лермонтова Ю.О., Сидоренко П.І., Терент'єва А.В., та інші. Проте це питання є актуальним у нашій державі.

Нормативно-правову базу України з домедичної допомоги складають:

Закон України від 05.07.2012 p. № 5081-VI «Про екстрену медичну допомогу» [3].

У статті 1 наводиться визначення домедичної допомоги, це: невідкладні дії та організаційні заходи, які направленні на врятування та збереження життя та здоров'я людини у невідкладному стані та зменшення наслідків дії на їх здоров'я, що надають пересічні громадяни або рятівники які не мають медичної освіти.

Статтею 12 визначаються особи, які зобов'язані надавати домедичну допомогу, це: рятувальники аварійно-рятувальних служб, працівники державної пожежної охорони, працівники органів та підрозділів міліції, фармацевтичні працівники, провідники пасажирських вагонів, бортпровідники та інші особи, які не мають медичної освіти, але за своїми службовими обов'язками повинні володіти практичними навичками надання домедичної допомоги.

Статтею 15 визначена відповідальність за порушення законодавства у сфері надання екстреної медичної допомоги - особи, винні у порушенні положень цього Закону, у порядку, встановленому законом, несуть дисциплінарну, адміністративну, кримінальну або цивільноправову відповідальність за ненадання без поважних причин на місці події домедичної допомоги або необгрунтовану відмову в ії̈ наданні. Тобто, співробітники аварійно-рятувальних служб та працівники державної пожежної охорони, а також працівники інших міністерств та відомств підпадають у разі ненадання домедичної допомоги (або не якісного надання) до відповідальності згідно зі статтею 367 (службова недбалість) Кримінального кодексу України.

Закон України від 02.10.2012 р. № 5403-VI «Кодекс цивільного захисту України» [4].

Статтею 17 пункт 22 визначено, що центральний орган виконавчої влади, який забезпечує формування та реалізує державну політику у сфері цивільного захисту, здійснює ліквідацію медико-санітарних наслідків надзвичайних ситуацій та надає екстрену медичну допомогу у зоні НC (осередку ураження) постраждалим та рятувальникам, заходи 3 медичного забезпечення (лікувально-профілактичні, санітарно-гігієнічні, медичне постачання та санаторно-курортне лікування) осіб рядового і начальницького складу, ветеранів служби цивільного захисту (війни) та членів їхніх сімей.

Статтею 23 пунктом 8 на аварійно-рятувальну службу покладено виконання таких завдань як: пошук і рятування людей на уражених об'єктах і територіях, надання у можливих межах невідкладної, у тому числі медичної, допомоги особам, які перебувають у небезпечному для життя й здоров'я стані, на місці події та під час евакуації до лікувальних закладів.

Постанова Кабінету Міністрів України «Про затвердження порядку підготовки та підвищення кваліфікації осіб, які зобов'язані надавати першу допомогу» від 21 листопада 2012 p. № 1115. Визначає процедуру підготовки та підвищення кваліфікації осіб, які згідно із своїми службовими обов'язками зобов'язані володіти знаннями і практичними навичками надання домедичної допомоги особам, які перебувають у невідкладному стані [5].

Наказом МОЗ України від 18.03.2005 р. № 120 "Про організацію навчання медичних та немедичних працівників 3 надання медичної допомоги в екстрених ситуаціях" затверджено:

Уніфіковану програму підготовки медичних працівників системи швидкої медичної допомоги та служби медицини катастроф з невідкладної медичної допомоги у надзвичайних ситуаціях.

Уніфіковану програму медичної підготовки рятувальників та інших фахівців, які беруть участь у ліквідації наслідків надзвичайних ситуацій і не мають медичної освіти.

Уніфіковану програму підготовки викладачів - інструкторів з надання медичної допомоги в екстремальних ситуаціях [6].

Наказ Міністерства охорони здоров'я України «Про затвердження порядків надання домедичної допомоги особам при невідкладних станах» від 16 червня 2014 р. № 398 та наказ Міністерства охорони здоров’я України «Про вдосконалення підготовки з надання домедичної допомоги осіб, які не мають медичної освіти» від 29 березня 2017 р. № 346. 
Чинними нормативними документами передбачено певні кваліфікаційні вимоги до осіб, що надають навчальні послуги з надання домедичної допомоги.

Відповідно до Теми 7 «Надання домедичної допомоги потерпілим у разі нещасного випадку» додатку 4 до п. 5.1 Типового положення про порядок проведення навчання i перевірки знань 3 питань охорони праці (НПАОП 0.00-4.12-05), затвердженого наказом Державного комітету України з нагляду за охороною праці від 26 січня 2005 р. № 15, навчання повинні проводити фахівці з медичною освітою.

Проте наявність медичної освіти не дає безумовного права на надання цих послуг.

У Довіднику кваліфікаційних характеристик професій працівників: Інструктор з надання догоспітальної допомоги має певні завдання та обов'язки. Керується Конституцією України, чинним законодавством України, іншими нормативно-правовими актами, що визначають діяльність закладів охорони здоров'я; здійснює методичне забезпечення і координацію роботи акредитованого навчально-тренувального структурного підрозділу установи, на базі якої проводиться навчання окремих категорій немедичних працівників та всіх, хто виявив бажання, надання догоспітальної допомоги; розробляє та готує навчальні матеріали відповідно до затверджених навчальних програм; організовує навчально-тренувальний процес, комплектує навчальні групи; аналізує результати навчально-тренувального процесу; сприяє комунікації між слухачами і координатором навчального центру; веде статистичний облік результатів роботи навчально-тренувального структурного підрозділу, етапів підготовки, узагальнює результати роботи; дотримується правил особистої та громадської безпеки і правил охорони праці; володіє прийомами реанімації, вміє надавати допомогу при травмах, кровотечах, серцево-судинних захворюваннях, колапсі, отруєнні, утепленні, механічній асфіксії, анафілактичному шоці, термічних та хімічних ураженнях, алергічних станах; дотримується принципів медичної деонтології; постійно удосконалює свій професійний рівень [7].

Інструктор з надання догоспітальної допомоги має знати Конституцію України, чинне законодавство України про охорону здоров'я та інші нормативні документи, що регламентують діяльність закладів охорони здоров'я; права, обов'язки і відповідальність інструктора 3 надання догоспітальної допомога; міжнародну класифікацію хвороб; клінічні настанови (протоколи) 3 медицини невідкладних станів та надання екстреної медичної допомоги; основи анатомії, патологічної анатомії, фізіології та патологічної фізіології людини; основи внутрішньої медицини, педіатрії, хірургії, акушерства та гінекології, травматології, урології, інфектології; імунології, етіологію та патогенез найбільш поширених захворювань, методи їх діагностики та принципи лікування; основні методи серцево-легеневої реанімації; особливості реанімації та інтенсивної терапії у дітей і новонароджених; принципи ведення фізіологічних пологів та розпізнавання патологічних; фармакологічну дію поширених лікарських речовин, показання та шляхи введення, їх сумісність, дозування; принципи роботи з наркозно-дихальною та іншою апаратурою, що застосовується бригадою екстреної медичної допомоги; принципи надання медичної допомоги потерпілим при надзвичайних ситуаціях 3 великою кількістю постраждалих, а також при виявленні особливо небезпечних інфекцій; правила оформлення медичної документації; правила медичної етики і деонтології, комунікації між співробітниками та іншими службами; правила безпеки під час роботи 3 медичним інструментарієм i обладнанням.

Щодо кваліфікаційних вимог, то вони висуваються відповідно до кваліфікаційної категорії.

Інструктор $з$ надання догоспітальної допомоги вищої кваліфікаційної категорії: вища освіта за ступенем молодшого бакалавра з будь-яких спеціальностей галузі знань «Охорона здоров'я». Підвищення кваліфікації (курси удосконалення тощо). Наявність посвідчення про присвоєння (підтвердження) вищої кваліфікаційної категорії з цієї кваліфікації. Стаж роботи за фахом - понад 10 років.

Інструктор з надання догоспітальної допомоги I кваліфікаційної категорії: вища освіта за ступенем молодшого бакалавра з будь-яких спеціальностей галузі знань «Охорона здоров'я». Підвищення кваліфікації (курси удосконалення тощо). Наявність посвідчення про присвоєння (підтвердження) I кваліфікаційної категорії з цієї кваліфікації. Стаж роботи за фахом - понад 7 років.

Інструктор з надання догоспітальної допомоги II кваліфікаційної категорії: вища освіта за ступенем молодшого бакалавра з будь-яких спеціальностей галузі знань «Охорона здоров'я». Підвищення кваліфікації (курси удосконалення тощо). Наявність посвідчення про присвоєння 
(підтвердження) II кваліфікаційної категорії з цієї кваліфікації. Стаж роботи за фахом - понад 5 років.

Інструктор 3 надання догоспітальної допомоги: вища освіта за ступенем молодшого бакалавра 3 будь-яких спеціальностей галузі знань «Охорона здоров'я». Наявність досвіду практичної роботи у сферах охорони здоров'я, цивільної безпеки, соціального захисту - не менше 2 років. Наявність сертифіката закладу, акредитованого МОЗ України, про проходження навчання за програмою підготовки за кваліфікацією «Інструктор 3 надання догоспітальної допомоги».

Окрім інструктора 3 надання догоспітальної допомоги у Довіднику кваліфікаційних характеристик професій працівників $є$ ще інструктор з надання першої допомоги [7].

Його завдання та обов'язки: керується Конституцією України, чинним законодавством України, іншими нормативно-правовими актами, що визначають діяльність закладів охорони здоров'я; здійснює методичне забезпечення і координацію роботи акредитованого навчальнотренувального структурного підрозділу установи, на базі якої проводиться навчання окремих категорій немедичних працівників та всіх, хто виявив бажання, надання першої допомоги; розробляє та готує навчальні матеріали відповідно до затверджених навчальних програм; організовує навчально-тренувальний процес, комплектує навчальні групи; аналізує результати навчально-тренувального процесу; сприяє комунікації між слухачами i координатором навчального центру; веде статистичний облік результатів роботи навчально-тренувального структурного підрозділу, етапів підготовки, узагальнює результати роботи; дотримується правил особистої та громадської безпеки і правил охорони праці; володіє прийомами реанімації, вміє надавати допомогу при травмах, кровотечах, серцево-судинних захворюваннях, колапсі, отруєнні, утопленні, механічній асфіксії, анафілактичному шоці, термічних та хімічних ураженнях, алергічних станах; дотримується принципів деонтології; постійно удосконалює свій професійний рівень.

Інструктор з надання першої допомоги повинен знати: Конституцію України, чинне законодавство України про охорону здоров'я та інші нормативні документи, що регламентують діяльність закладів охорони здоров'я; права, обов'язки і відповідальність інструктора 3 надання першої допомоги; основи анатомії, патологічної анатомії, фізіології та патологічної фізіології людини; основи травматології, інфектології; імунології; основні методи серцево-легеневої реанімації; особливості реанімації у дітей і новонароджених; принципи ведення фізіологічних пологів та розпізнавання патологічних; принципи сортування та надання першої допомоги потерпілим при надзвичайних ситуаціях з великою кількістю постраждалих; правила етики i деонтології, комунікації з службами екстреної допомоги населенню; правила безпеки під час роботи з медичним обладнанням.

Для інструктора 3 надання першої допомоги також висуваються певні кваліфікаційні вимоги відповідно до кваліфікаційної категорії.

Інструктор з надання першої допомоги вищої кваліфікаційної категорії: вища освіта за ступенем молодшого бакалавра з будь-яких спеціальностей. Підвищення кваліфікації (курси удосконалення тощо). Наявність посвідчення про присвоєння (підтвердження) вищої кваліфікаційної категорії з цієї кваліфікації. Стаж роботи за фахом - понад 10 років.

Інструктор 3 надання першої допомоги I кваліфікаційної категорії: вища освіта за ступенем молодшого бакалавра з будь-яких спеціальностей. Підвищення кваліфікації (курси удосконалення тощо). Наявність посвідчення про присвоєння (підтвердження) I кваліфікаційної категорії з цієї кваліфікації. Стаж роботи за фахом - понад 7 років

Інструктор з надання першої допомоги II кваліфікаційної категорії: вища освіта за ступенем молодшого бакалавра з будь-яких спеціальностей. Підвищення кваліфікації (курси удосконалення тощо). Наявність посвідчення про присвоєння (підтвердження) II кваліфікаційної категорії з цієї кваліфікації. Стаж роботи за фахом - понад 5 років.

Інструктор з надання першої допомоги: вища освіта за ступенем молодшого бакалавра 3 будь-яких спеціальностей. Наявність сертифіката закладу, акредитованого МОЗ України, про проходження навчання за програмою підготовки за кваліфікацією «Інструктор 3 надання першої допомоги». Наявність досвіду надання першої допомоги [7].

На сьогодні законодавством передбачені програми підготовки та підвищення кваліфікації I, II, III рівнів, які мають, відповідно, 8, 48, 120 навчальних годин. Навчальна година складає 60 хвилин. Тривалість щоденного навчання не має перевищувати 8 годин (накази Міністерства охорони здоров'я України «Про організацію навчання окремих категорій немедичних 
працівників навичкам надання першої невідкладної медичної допомоги» від 2 березня 2009 p. № 132 та «Про удосконалення підготовки з надання домедичної допомоги осіб, які не мають медичної освіти» від 29 березня 2017 р. № 346) [1].

Періодичність підвищення кваліфікації немедичних працівників встановлена 1 раз на 3 роки.

Основою всіх тренінгів має бути «алгоритм базової підтримки життя» (Basic Life Support) [8].

Алгоритм базової підтримки життя (Basic Life Support)

1. Розпізнавання зупинки дихання та кровообігу.

2. Порядок виклику бригади швидкої допомоги.

3. Проведення якісної серцево-легеневої реанімації.

4. Використання АЗД (автоматичного зовнішнього дефібрилятора).

5. Допомога при обструкції дихальних шляхів стороннім тілом (прийом Геймліха) [8].

Також необхідно відпрацьовувати навички щодо:

- зупинки кровотечі з кінцівок методом прямого тиску на рану, накладання тиснучої пов'язки та джгута (Есмарха та турнікету);

- допомоги при:

- травмах опорно-рухового апарату (забої, вивихи та переломи);

- термічних ураженнях;

- судомах;

- порушеннях мозкового кровообігу (інсульту) та серцевого (інфаркту).

Основною умовою успішного навчання $\epsilon$ відпрацювання навичок в умовах навчальної симуляції: командна робота з надання допомоги в різних ситуаціях.

Проходження навчання раз на рік та перепідготовка працівників дасть змозу зменшити тяжкість травматизму та кількість потерпілих від нещасних випадків у разі надзвичайної ситуації чи загострення хвороби.

Для збереження навичок та удосконалення працівникам рекомендується після проходження курсу проходити Refresh-тренінги не рідше разу на рік після проходження курсу. Це дасть можливість поновити практичні навички та визначити приховані недоліки системи реагування на надзвичайні ситуації.

Ще один основним аспект це аптечка 3 домедичної допомоги. Вона має бути укомплектована відповідно до специфіки даного виробництва та надати можливість зберегти життя і здоров'я потерпілого до прибуття фахівців екстреної медичної допомоги. Перед формуванням набору в аптечку потрібно залучити «аудит» із питань домедичної допомоги та виявити ті загрози й можливі ураження, що можуть бути на території цеху, виробничого майданчика та в приміщеннях підприємства [9].

Місця розташування аптечки мають бути враховані та оптимізовані таким чином, щоб від місця події до аптечки можна було дістатися за найкоротший проміжок часу. Як приклад, на кожному підприємстві $є$ пожежні щити та розташовані вогнегасники. А отже, аптечки домедичної допомоги треба розташовувати в тих же місцях 3 обов'язковим позначанням міжнародним знаком First Aid (білий хрест на зеленому тлі).

Яким би повним та об’ ємним не був набір «Аптечки домедичної допомоги», його якість використання залежить від людей - працівників підприємства. Якщо працівник не проходив відповідних навчань 3 домедичної допомоги та цей набір він отримав уперше, це вкрай негативно позначиться на часі та якості надання першої допомоги постраждалому.

Будь-який набір аптечки потрібно розбирати на навчанні, працівники повинні вміти користуватися тими медикаментами та приладдям, що містяться в цьому наборі.

Найчастіше на виробництві людина зазнає таких пошкоджень, як:

- раптова зупинка кровообігу внаслідок серцевої недостатності або інсульту;

- поранення з критичною кровотечею (венозною та артеріальною);

- опіки різних частин тіла та обличчя;

- травми опорно-рухового апарату;

- пошкодження хребта.

Основні принципи надання першої допомоги:

- правильність і доцільність (якщо ви не впевнені в своїх діях - краще утриматись; головне правило першої допомоги - не нашкодити);

- швидкість; 
- продуманість, рішучість, спокій.

Алгоритм дій має бути таким:

1. Оглянути місце події та впевнитись у тому, що надання допомоги буде безпечним: забезпечити власну безпеку, а також безпеку потерпілого та людей навколо.

2. Оцінити стан постраждалого (свідомість, дихання, пульс).

3. За необхідності викликати бригаду екстреної (швидкої) медичної допомоги, а також інші екстрені служби (поліцію, аварійно-рятувальну службу, службу газу тощо).

4. Оцінити наявність критичних кровотеч та зупинити їх.

5. Забезпечити прохідність дихальних шляхів.

6. Якщо у постраждалого відсутні ознаки життя та немає критичної кровотечі (або ви вже іiі ліквідували) - розпочати серцево-легеневу реанімацію.

7. Перевести постраждалого у стабільне положення (на боці, обличчям до себе, рука під головою, нога зігнута в коліні), якщо не йдеться про підозру на травми хребта та кісток тазу і серцево-легенева реанімація була вдалою.

8. Не залишати постраждалого та контролювати стан його життєвих функцій до прибуття екстрених служб.

Висновки. $€$ нагальна необхідність вивчити закордонний досвід, так як наразі це питання майже не розглядалось дослідниками.

Нажаль в Україні питання навчання та уміння надання першої допомоги практично не вирішено. Тому проведення навчання $є$ необхідним на будь якому підприємстві, а особливо це стосується виробничих сфер.

Кожен свідомий українець повинен пройти курси з надання першої допомоги і отримати практичні навички. Адже саме ці навики можуть врятувати чиєсь життя в критичній ситуації.

\section{Інформаційні джерела}

1. Картавий О. Усе про домедичну допомогу // Охорона праці. - №11. - 2019.

2. Волянський П.Б. Домедична допомога як складова сучасної системи реагування на надзвичайні ситуації / П. Б. Волянський, А. М. Макаренко. // Державне управління: удосконалення та розвиток № 12, 2015.

3. Закон України від 05.07.2012 р. № 5081-VI «Про екстрену медичну допомогу».

4. Закон України від 02.10.2012 р. № 5403-VI «Кодекс цивільного захисту України».

5. Постанова Кабінету Міністрів України від 21 листопада 2012 р № 1115 «Порядок підготовки та підвищення кваліфікації осіб, які зобов'язані надавати до медичну допомогу».

6. Наказ Міністерства охорони здоров’я України від 18.03.2005 p № 120 «Про організацію навчання медичних та немедичних працівників 3 надання медичної допомоги в екстрених ситуаціях».

7. Довіднику кваліфікаційних характеристик професій працівників Випуск 78 «Охорона здоров'я», затвердженому наказом Міністерства охорони здоров'я України від 29 березня 2002 р. № 117, зі змінами, внесеними наказом Міністерства охорони здоров’я України від 9 серпня 2017 р. № 918.

8. Картавий О. Організація навчання 3 домедичної допомоги на підприємстві . / О.Картавий // «Охорона праці і пожежна безпека» №7, 2019/

9. Картавий О. Комплектація аптечки для надання домедичної допомоги (для виробничих підрозділів машинобудівної галузі). / О. Картавий, Т. Білько // „Юхорона праці і пожежна безпека» №2, 2019.

\section{Висын Е.А., Федорчук-Мороз В.И. \\ ОСНОВНЫЕ АСПЕКТЫ ДОМЕДИЦИНСКОЙ ПОМОЩИ}

В статье освещены основные аспекты домедищинской помощи. Приведенная нормативно - правовая база основы проведения обучения по домедицинской помощи. Освещены программы по которым проводится обучение с домедицинской помощи пострадавщему и приведен перечень навыков, которыми должны овладеть слушатели после окончания учебы. $B$ Украине средний показатель смертности в результате чрезвычайных ситуаиий - 130-135 человек на 100 тыс. Населения (по данным ДСНС), что в 3-5 раз превышает показатели стран Eвропьы.

На догоспитальном этапе умирает 76\% пострадавщих, в больницах - 24\%. В развитых странах мира на догоспитальном этапе умирает 28\%, в больницах - $72 \%$. 
Так происходит потому, что из 100 человек, умерших на догоспитальном этапе, примерно $20 \%$ получили несовместимые с жизнью травмы, а смерть $80 \%$ пострадавших наступила в результате неэффективной эвакуации в лечебные учреждения и неправильно организованной домедицинской помощи непосредственно в зоне чрезвычайной ситуачии. Если рядом с травмированным нет человека, который по своим служебным обязанностям должна обладать основныли навыками по спасению и сохранению жизни, оказывать помощь должен тот, кто поблизости. Действия спасителя должны быть быстрыми, продуманными, решительныли и целесообразными. Нужно уметь делать это правильно, ведь главный принцип при предоставлении домедицинской помощи не навредить. Хотя в чрезвычайную ситуацию сохранять спокойствие достаточно сложно, поможет в этом четкое осознание того, что делаешь и с какой иелью.

Ключевые слова: домедициской помощь, обучение, умение, нормативно-правовая база, аптечка.

\section{Visyn E.A., Fedorchuk-Moroz V.I.}

\section{BASIC ASPECTS OF HOME CARE}

The article highlights the main aspects of home care. The legal and legal basis for conducting training in domedical assistance is given. The programs that provide training in domedic assistance to the victim are outlined and a list of skills that trainees need to master after graduation.

In Ukraine, the average mortality rate due to emergencies is 130-135 people per 100,000 population (according to the SESP), which is 3-5 times higher than in Europe.

At pre-hospital stage, $76 \%$ of victims die, in hospitals - 24\%. In developed countries, $28 \%$ die in the pre-hospital phase, and $72 \%$ in hospitals.

This is because, out of 100 people who died in the pre-hospital phase, approximately $20 \%$ were incompatible with life trauma, and the deaths of $80 \%$ of the victims were due to inefficient evacuation to medical institutions and improperly organized domedic care directly in the emergency area.

If there is no person next to the injured person who must have basic practical life-saving and life-saving skills in their duties, then someone nearby should help. The lifeguard's actions must be fast, thoughtful, decisive and appropriate. You need to be able to do it right, because the main principle when providing domedic help is not to hurt.

Although it is difficult to keep calm in an emergency, it will help in this clear understanding of what you are doing and for what purpose.

Keywords: domedic assistance, training, skills, legal framework, first aid kit. 